\title{
Human Beings Trafficking. the Albanian Legislation
}

\author{
Nikolin Hasani, Ph.D \\ University "Ismail Qemali" Vlore \\ Faculty of Human Sciences, Department of Law \\ nikolin.hasani@univlora.edu.al
}

Abstract

\begin{abstract}
Human trafficking has emerged as a negative phenomenon, with a large multiple social risks, primarily based on human rights violations practices, on the continuous victimization of people and the denial of human dignity. Economic recession, cultural and rural families, tin heterogeneity of the urban population are also other factors which facilitate domestic trafficking. Albania's geographical position at the external borders of the EU is a mitigating factor for Albanians and other populations in the region to move towards Europe illegally. The aim of this paper is to presents the legal aspects of trafficking in human beings in Albania after the communism regime.
\end{abstract}

Keywords: human trafficing, traficing victims, Albanian legislation.

\section{Introduction}

Organized crime and human trafficking today poses a serious threat to security in all democratic countries, especially has recently proved that no state is completely safe from organized crime and human trafficking activity regardless of the state's territorial size, power, religion, color, political regulation.

There are different ways of describing human beings trafficking, and different research of the field describes it as a modern form of slavery. It is internationally defined as "the recruitment, transportation, transfer, harbouring or receipt of persons, by means of the threat or use of force or other forms of coercion, of abduction, of fraud, of deception, of the abuse of power or of a position of vulnerability or of the giving or receiving of payments or benefits to achieve the consent of a person having control over another person, for the purpose of exploitation.

\section{Forms of international trafficking of human beings in Albania after the fall of Communism}

Among the main forms of international trafficking of people during the post-communist in Albania were:

1. Through the sea crossing by vessels, without documents.

2. Through land border crossing avoiding Ollie -count border.

3. Through the crossing in the border checkpoints with false documents.

These forms are exploited for all categories of persons who are trafficked, as for Albanian citizens as well as for foreign citizens, as for women that are exploited for prostitution as well as for minors.

Sea crossing by vessels, without documents

For the realization of this trafficking first were used the Albanian vessels as fishing boats, merchant ships, speedboats and seeing that the profits were large, by getting in touch with Italian traffickers, bought fast vessels as speedboats and boat with motors with large force, making it possible in this time the fast sea crossing and raised the possibility of salvation of control mainly by Italian patrol ships. During the years 1993-1999 the fast speed vessels reached hundreds and used mainly for this trafficking bay of Vlora, mouth of Vjosa River, mouth of Shkumbin River, bay of Kavaja and Durres, and the bay of Shengjin.

Land border crossing avoiding border crossing points 
This form of trafficking initially is expressed in the form of guidelines, taking small remunerations for this activity and then is organized in trafficker networks. Passage of Albanians to Greece via this form has had also painful events, but has been decreasing as a result of finding of other opportunities. Actually are using by traffickers networks to bring in Albania victims of foreign trafficking that exploits Albania as transit country to the west. Are used for this purpose the mountain thoroughfares and difficult terrains or through the crossing in lake, exploits the dark and the lack of control.

\section{Crossing through the border crossing points using false documents}

The crossing through the border checkpoints is the most organized form of traffickers because exists the cooperation between the traffickers with forgers and employees that abuse in task. This form is observed in almost all border crossing points, especially at Rinas Airport, the Port of Durres and Vlora, as for Albanian citizens as well as for foreigners. During the years 1993-1998 this form is widely used and the findings by the police have been scarce. After the year 1998 are identified hundred cases of return of Albanian citizens with irregular documents from these crossing points, as well as the returns of foreign citizens that did not fulfill the criteria to enter in Albania. This is the form used more often for the trafficking of foreign women with the purpose of of exploitation for prostitution, because this way has been costly due to separation benefits between criminal groups. Currently, according to the data declared from the Italian police it is said about a significantly decrease of this traffic, while the Albanian border police statistics show only sporadic cases in some border crossing points.

\section{Albanian legislation on human beings trafficking}

Many countries have adopted the national laws to cope with the phenomenon of human beings trafficking in accordance with Palermo Protocol. Albania has signed the Convention of the Council of Europe "On Measures against Trafficking of Human Beings" and ratified it by the Assembly. It should be noted that for some legislative systems the meaning and the status of "the crimes victims" is specified in the Criminal Code and in this case the terms and conditions of the definition should be included in the juristic assessment. Whatever is the legal definition used, the target is to be considered the specific circumstances in each case and to be compared with legal references.

In Albanian legislation is given the definition for some criminal offenses which includes the trafficking of peoples as:

Trafficking of persons: Recruitment, transportation, transfer, hiding or recipient of persons through the threat or use of force or the other forms of coercion, kidnapping, fraud, the abuse of power or profiting by social, physical or psychic condition, or giving or receiving of payments or profits to achieve the consent of person who control another person with purpose of prostitution exploitation of the others or the other form of sexual exploitation, force work or service, slavery or similar forms to slavery, putting in use or transplanting of organs and other forms of exploitation ".

Trafficking of women: Recruitment, transportation, transfer, hiding or recipient of women through the threat or use of force or the other forms of coercion, kidnapping, fraud, the abuse of power or profiting by social, physical or psychic condition, or giving or receiving of payments or profits to achieve the consent of person who control another person with purpose of prostitution exploitation of the others or the other form of sexual exploitation, force work or service, slavery or similar forms to slavery, putting in use or transplanting of organs and other forms of exploitation ".

Trafficking of minors: recruitment, transportation, transfer, hiding or recipient of minors with purpose of prostitution exploitation of the others or the other form of sexual exploitation, force work or service, slavery or similar forms to slavery, putting in use or transplanting of organs and other forms of exploitation".

Assistance for illegal border crossing: Housing, accompaniment, making available or the use of navigation and flight means or other means of transport or any other assistance with purpose of illegal crossing of the border of the Republic of Albania or for illegal entry of a person in another state without being its citizen, or that has not a resident permit in that state.

The Criminal Code of Republic of Albania not only has made a proper approach to definition, but in specific articles has provided specific aspects which are related with human beings trafficking such as: Article 114/b - trafficking of women, Article 128/b - trafficking of minors; Article 109 - the kidnapping and hostage-taking; Article 110 - unlawful deprivation of freedom; Article 114 - exploitation of prostitution ; Article 114/a - exploitation of prostitution in aggravating circumstances; Article 115 - maintaining of premises for prostitution; Article 116 - homosexuality; Article 117 - pornography; Article 129 pushing of minors in crime. 
Forms of illegal trafficking of human beings, provided by Criminal Code of Republic of Albania and encountered during investigations conducted in years are criminal offenses provided by articles 110/a - "Trafficking of persons", 114/b - " Trafficking of women", and 128/b - "Trafficking of minors" are: Recruitment, transportation, transfer, hiding or recipient of persons/women/minors through the threat or use of force or the other forms of coercion, kidnapping, fraud, the abuse of power or profiting by social, physical or psychic condition, or giving or receiving of payments or profits to achieve the consent of person who control another person. Referring to the current situation of trafficking in human beings, in terms of the Second Additional Protocol of the Palermo Convention, is concluded that for years Albania is no longer a transit country for victims of trafficking. Albania currently is considered country mainly of origin and with tendencies of a country of arrival mainly regarding to internal trafficking. On the whole, the victims of trafficking are Albanian new women recruited mainly in rural areas, which are trafficked mainly in the countries of EU and where the main form of exploitation is that of prostitution or for other sexual services. The countries of arrival for the use of the Albanian victims are mainly Italy, United Kingdom, France, Belgium, Norway, Germany, Holland, Kosovo, Macedonia and other countries of Western Europe.

In lesser extend is observed the trafficking of children, mainly form the Rom and Egyptian communities, who are trafficking mainly in Greece, Italia or Kosovo, with the purpose of their exploitation for begging or illegal adoptions. The main form of recruitments remains the fraud that the authors of these offenses make to their women victims for marriage or cohabitation abroad. In this way the organize fraud scheme deceiving with customary rites and ceremony not only the victim but also her family circle. Referring the ways followed to send the victims in the countries of arrival it should be noted that they are mostly through providing false documents and their journey by land and rarely by air and naval. By the analysis of statistic data in years, results that the tendency of this phenomenon is in significant reduction because of the comprehensive measures taken by the Albanian state in terms of increasing of awareness of social groups at risk, but also for reason of a war without compromise made by specialized structures of law enforcement. The creation of appropriate legal framework, particularly severe and applied penalties and the seizure of criminal assets of authors of these offenses have given their impact in aspect of general prevention. It should be noted that assistance for illegal crossing of the border is accompanied by housing, accompany, availability or use of means of sea, air or other means of transport, in order to help the illegal crossing of the border, while contraband of people is a phenomenon that is prompted by a series of socio-economic factors and a very severe politic on issuing visas. It appears mainly in the form of assistance that various people resident near to land borders, give to illegal immigrants against the payments that are made mainly when the person is in destination. Also are observed criminal organized small groups which collaborate with groups or peoples abroad in the lines that follow the contraband.

The most encountered forms are:

1. The organization of persons in small groups and their accompaniment until near the border crossing points. Then accompanied by certain people, the groups cross walking the border with Greece, out of border crossing points. In these cases the persons dispose forged identity documents.

2. The providing of citizen with visas by embassies based on wholly or partly forged documentation mandatory to be presented for a visa.

The persons cross the Albanian state border through crossing points with Border States which have not visa regime (Macedonia, Kosovo, Montenegro) and then led by the other persons, is made the crossing to the country of arrival.

In Albanian penal legislation are made some changes, which aim to further strengthening of legal framework. Changes consider punitive policies provided by the following Articles:

Article 110/a, Trafficking of persons: "Recruitment, transportation, transfer, hiding or recipient of persons through the threat or use of force or the other forms of coercion, kidnapping, fraud, the abuse of power or profiting by social, physical or psychic condition, or giving or receiving of payments or profits to achieve the consent of person who control another person with purpose of prostitution exploitation of the others or the other form of sexual exploitation, force work or service, slavery or similar forms to slavery, putting in use or transplanting of organs and other forms of exploitation (5-15 years imprisonment and fine of 2-5 million leke)".

Article 114/b, Trafficking of women: "Recruitment, transportation, transfer, hiding or recipient of women through the threat or use of force or the other forms of coercion, kidnapping, fraud, the abuse of power or profiting by social, physical or psychic condition, or giving or receiving of payments or profits to achieve the consent of person who control another person with purpose of prostitution exploitation of the others or the other form of sexual exploitation, force work or service, 
slavery or similar forms to slavery, putting in use or transplanting of organs and other forms of exploitation (7-15 years imprisonment and fine of 3-6 million leke)". The organization, management and financing of trafficking of women (10-15 years imprisonment and fine of 5-7 million leke). When this offense is conducted in collaboration or more than once or is associated with maltreatment and coercion with physical or psychological violence against the victim to do various actions or bring severe consequence for the health (not less than 15 years imprisonment and fine of 6-8 million leke). When the offense has brought as consequence the death of the injured (not less than 20 years imprisonment or life imprisonment and fine of 7-10 million leke). When the criminal offense is conducted by the utilization of state function or public service (one fourth additional of imprisonment and fine).

Article 128/b, Trafficking of minors: "Recruitment, transportation, transfer, hiding or recipient of minors with purpose of prostitution exploitation of the others or the other form of sexual exploitation, force work or service, slavery or similar forms to slavery, putting in use or transplanting of organs and other forms of exploitation (7-15 years of imprisonment and fine of 4-6 million leke). The organization, management and financing of trafficking of minors (10-20 years imprisonment and fine of 6-8 million leke). When this offense is conducted in collaboration or more than once or is associated with maltreatment and coercion with physical or psychological violence against the victim to do various actions or bring severe consequence for the health (not less than 15 years imprisonment and fine of 6-8 million leke). When the offense has brought as consequence the death of the injured (not less than 20 years imprisonment or life imprisonment and fine of 8-10 million leke). When the criminal offense is conducted by utilization of state function or public service (one fourth additional of imprisonment and fine).

Article 114/a, Exploitation of prostitution in aggravating circumstances:

"Exploitation of prostitution conducted: 1. with the minors; 2. against some persons; 3 . With persons with whom exist close relation of gender, intermarry, custody or profited from official reports; 4 . with fraud, coercion, violence or profiting from the physical or mental inability of the person; 5 .against to a person being pushed or coerced to exercise prostitution outside the territory of the Republic of Albania; 6 .is conducted in collaboration or more than once or by persons charged with state and public functions (7-15 years imprisonment)"

Article 297, Illegal crossing of the state border: "Illegal crossing of the state border constitutes penal contravention (fine or imprisonment till 2 years)".

Article 298, Assistance for illegal border crossing: "Housing, accompaniment, making available or the use of navigation and flight means or other means of transport or any other assistance with purpose of illegal crossing of the border of the Republic of Albania or for illegal entry of a person in another state without being its citizen, or that has not a resident permit in that state constitutes penal contravention ( 1-4 years imprisonment and fine of 3-6 million leke)". When the assistance is given for profit purposes (3-7 years imprisonment and fine of 4-8 million leke). When this offense is conducted in collaboration or more than once or has brought sever consequences (5-10 years imprisonment and fine 6-8 million leke). When the offense has brought as consequence the death of the injured (not less than 15 years imprisonment or life imprisonment and fine of 8-10 million leke). When the criminal offense is conducted by the utilization of state function or public service (one fourth additional of imprisonment and fine).

Article 113, Prostitution: "The exercise of prostitution (fine or imprisonment till 3 years)".

Article 114, The exploitation of prostitution: "Pushing, intermediation or receiving the remuneration for the exercise of prostitution (fine or imprisonment till 5 years)".

Article 115, the maintaining of premises for prostitution: "maintaining exploitation, financing, rental of premises for the purposes of prostitution (fine or imprisonment till ten years)".

Also in Penal Code is added a new disposition against the exploitation of children for forced work, which will be accompanied by a new socio-educational set for assistance to these children and their families in the form of employment, education and other types of assistance. Punitive policies against the perpetrators of these criminal acts are an important factor in the prevention of trafficking, but if these policies are not supported by other national policies, and even international, such policies will fail to impact on prevention of human beings trafficking.

At the national level, in the war against trafficking of human beings and the prevention of this phenomenon are engaged a number of state and non-state institutions such as: The sector against illegal trafficking in Interior Ministry, General Prosecutor; The Directory against Organized Crime; State Information Service, Defense Ministry, National Center of 
reception of Trafficking Victims, and other Shelter led by non-profit organizations, are the state and non-state institutions engaged not only in fighting but also in prevention of trafficking. Also in Durres is set up and operates Inter-institutional Maritime Operational Centre that has as mission the prevention of illegal trafficking through the sea. Any institution or organization has a specific policy for the prevention of trafficking.

\section{Conclusions}

Trafficking of human beings is today one of most active activities of organized crime. This criminal activity of international criminal groups and organizations, favored by social, economic, cultural, legal etc reasons of countries in transition, based on physical, sexual exploitation, besides financial enrichment of criminal groups, is associated with sever physical, psychic moral and social consequences for the victims of this trafficking.

Statistics between the large number of trafficked and small number of identified victims and treated as victims of trafficking show that the method of detection of victims of trafficking in human beings must be perfected and improved further.

Not identification and not treatment of victims of trafficking from state and non-state institutions engaged for this purpose, constitutes a potential risk for re-trafficking of them, and hinders the hitting of criminal activity of criminal groups and criminal organizations involved in this criminality.

Cooperation between different states structures with non state organizations specialized for this purpose increases the efficiency as in identification of victims of trafficking as well as in their further treatment.

The legal treatment of every case of trafficking of victims must be always associated with administrative treatment of trafficked victims, because always the victims need to repair the damages and consequences caused during the time of exploitation in trafficking, as well as their full re-integration in society is a complex process

Drafting of right legal punitive policies in accordance with legal acts and international recommendations, harmonization of these policies with the other psycho - social, national policies, are a necessity for the prevention of human beings trafficking. Punitive policies and psycho-social policies are in continuation of each other and in full function of each other.

The establishment of national and international mechanisms for identification, reference and treatment of victims of trafficking of human beings is a legal traverse to the activity of criminal organizations that today have a stretch not only regional, but also international.

\section{References}

Chankseliani, M. Punishement and other penal measures. European Scientific Journal February, Special edition vol. 8 , No.2, print ISSN: 1857 - 7881, e - ISSN 1857- 7431, pg.98 - 108.

Davidson, J. (2003). A eshte trafikimi i qenieve njerezore i nxitur nga kerkesa? Studim pilot ne shume vende. Gjeneve, IOM, 2003.

Elezi, M. (2013). Disa forma te trafikimit te qenieve njerezore ne Shqiperine postkomuniste. Hulumtime Shkencore, Shtepia botuese "Kristal", pg. 41 - 54, ISSN: 2226-1605.

Friman, H. Richard; Reich, Simon, 2007, Human Trafficking, Human Security and the Balkans, Pittsburgh, PA : University of Pittsburgh Press.

Imeraj, E. (2015). Trafficking in human beings for sexual causes in Albania. Applied Science Reports, 12 (3), 2015: 150 154, E-ISSN: 2310-9440 / P-ISSN: 2311-0139. DOI: 10.15192/PSCP.ASR.2015.12.3.150154.

Jolluck, K. (2012). Combating the Trafficking of Women in Eastern Europe. Program on Human Rights, Center on Democracy, Development, and the Rule of Law Freeman Spogli Institute for International Studies.

Kajtazi, R. (2015). Trafficking in human beings: legal aspects and forms of reporting in Kosovo. European Journal of Research in Social Sciences Vol. 3 No. 5, 2015, ISSN 2056-5429. 
Kodi Penal i Republikes se Shqiperise, miratuar me ligjin nr. 9686, date 26.02.2007.

Konventa e Kombeve te Bashkuara Kunder Krimit te Organizuar Trans-nacional dhe Protokolli ne plotesim te asaj Konvente "Mbi Parandalimin, Shtypjen dhe Denimin e Trafikimit te Personave, vecanerisht te Grave dhe Femijeve" (Protokolli i Palermos), 2000.

Konventa e Kombeve te Bashkuara Kunder Krimit te Organizuar Trans-nacional dhe Protokolli per plotesimin e asaj Konvente "Mbi Parandalimin, Shtypjen dhe Denimin e Trafikimit te Personave, vecanerisht te Grave dhe Femijeve" (Protokolli i Palermos). 2000.

Korvinus, A. (2005). Dutch National Rapporteur on Trafficking in Human Beings. Trafficking in Human Beings, Third report of the Dutch National Rapporteur, Bureau NRM, The Hague.

Ligji Nr. 8920, date 11.07.2002 "Per ratifikimin e Konventes se Kombeve te Bashkuara kunder krimit te organizuar nderkombetar", Fletore Zyrtare, nr. 41, viti 2002.

Ligji Nr. 9642, date 20.11.2006, "Per ratifikimin e Konventes se Keshillit te Evropes "Per Masat kunder Trafikimit te Qenieve Njerezore".

Ligji Nr. 9642, date 20.11.2006, "Per ratifikimin e Konventes se Keshillit te Evropes "Per Masat kunder Trafikimit te Qenieve Njerezore".

Neni 110/a i Kodit Penal te Republikes se Shqiperise

Neni 114/b i Kodit Penal te Republikes se Shqiperise

Neni 128/b i Kodit Penal te Republikes se Shqiperise

Neni 298 i Kodit Penal te Republikes se Shqiperise

Neni 298 i Kodit Penal viii Ligji nr.8920, date 11.07.2002 "Per ratifikimin e Konventes se Kombeve te Bashkuara kunder krimit te organizuar nderkombetar", Fletore Zyrtare, nr. 41, viti 2002, faqe 1195 v viiues.

Popa, G., Marczuk, K. ( Trafficking in Human Beings in the Post-Communist States of the Balkan Area. Human Security Journal, Volume 6, Spring 2008, pg. $78-88$.

Scarpa, S. (2008). Trafficking in human beings: modern slavery. Oxford University Press, pp. 2.

Sza'raz, K. (2010). The role of the European Union in the global fight against trafficking in human beings.

Touzenis, K. (2010). Traffiking in human beings. Human rights and trans-national criminal law, developments in law and practices. UNESCO migration studies 3. Series editors: Paul de Guchteneire and Antoine Pécoud.

United nations. Human Rights. Office of the High Commisioner. Human Rights and Human Trafficking. Fact Sheet No. 36.

Wijers, M. (2005). Analysis of the definition of trafficking in human beings in the Palermo Protocol. 